\title{
Language
}

\section{The Illusion of Linguistic Singularity, or the Monolingual Imagination}

In cases such as that of Japan, it may seem obvious to group texts, and bulwark the imagination of a national literature, through the notion of linguistic commonality. Unlike the category of ethnicity, which remains a powerful logic despite frequent disavowals of it, the category of language seems far less obviously problematic; it is of little surprise that (as will be discussed below) people have turned to it as a commonsensical solution to the implicit essentialist claims that undergird the ethnic logic. It seems almost tautological to say that one aspect of anything we might call modern Japanese literature (at least in a form that we might consider "original," rather than mediated through the process of translation) is that it be written in "Japanese." This is consonant with the post-World War II forgetting, or effacement, of the multilingual and multiethnic history of Japan described by scholars such as Oguma Eiji and Leo Ching. ${ }^{1}$ While this logic may seem sensible and intuitive when considering the historical interrelation of texts (both their production and their consumption), it is not as self-evident as it might appear, and in fact elides a great deal of complexity and heterogeneity. Though the focus of this chapter will be on the literary activities of prewar Brazil, this fact obtains in one form or another in all literary production, though in different forms and to differing degrees.

In the case of Brazil, one of the many massive upheavals experienced by emigrants from Japan was their immersion in a linguistic environment of greater complexity than most of them had ever experienced before. They were not only moving to a country in which the dominant (and official) language was Portuguese and encountering individuals (particularly at sea) who used English as their preferred mode of communication, but also coming into contact with a greater variety of idioms of Japanese than most had previously encountered. This diversity 
reminds us of the complexity of individual identification of the migrants, for whom self-imagining as national or ethnic subjects might have been less common in everyday life than self-imagining based on prefecture or region of origin, occupation, gender, or class, all of which had the potential to be conflated with dialectical difference. While depictions of this diversity seem to suggest that it rarely impeded mutual comprehensibility, the differences were obvious enough to be noted frequently in their fiction.

Given the complexity of this linguistic environment, it should come as no surprise that the literary works written by these Japanese speakers in Brazil-like other literary works set outside of Japan-would often address linguistic heterogeneity directly. Focusing on the specific representations occurring in Japaneselanguage literature written in Brazil, however, should not be taken to imply that the texts normatively thought of as "modern Japanese literature" are a monolithic collection of linguistically homogeneous texts. This is true not only of texts with settings outside of Japan or characters who are not Japanese, but also in texts that represent regional dialects or other forms of linguistic experimentation that deviates from the relatively standardized language for modern fiction (not to mention national language policy) based on the Tokyo dialect. While regional dialects are often seen as merely variations within a single language, it is valuable to recall that the divide between a language and a dialect is not as bright a line as it is often treated as being, even when one considers the most intuitive justification for such a distinction: mutual intelligibility. ${ }^{2}$ While dialects are often (but not always) treated diegetically as comprehensible to other characters and are non-diegetically presented in a way that presumes sufficient comprehensibility to the readers of the texts, it should not be presumed that the difference goes unnoticed, or that it actually is fully comprehensible to all readers.

The monolingual (even if heteroglossic) form that most novels takeparticularly when their narratorial perspective is limited to that of a single character-faces fundamental challenges when attempting to represent a multilingual environment. ${ }^{3}$ What would fiction be for a broad audience if all of the information gaps present in intersubjective communication were somehow maintained in the literary text? While some writers minimize or ignore those gaps, many others struggle to convey them, though usually in a moderated fashion that balances verisimilitude with comprehensibility. Representing these challenges to communication in literary texts poses multiple difficulties to writers, not only in terms of the impact that they will have on their potential audiences but also in terms of the basic mechanics of inscription. These challenges remind us of the ways in which the written literary form is anything but natural and transparent, but is instead the result of technical choices that have significant impact on what can be represented, and how.

The situation in Brazil brought many of these issues into relief. Immigrants from Japan found themselves in a multilingual environment even when they 
resided in the Japanese-language dominant colônias in the interior. Additionally, their “fellow Japanese," or “countrymen" (同胞), comprised a geographically (and linguistically) diverse group of individuals, hailing from prefectures stretching from Okinawa to Hokkaidō. Living side by side, they were keenly aware of the linguistic differences in the "Japanese" language that they were using (as well as the status and cultural differences that those differences would often be taken as signaling.) Literary texts produced in Brazil regularly address these differences. These texts not only give us insight into the linguistic aspects of the migration experience, but also concrete examples of the linguistic diversity of "Japaneselanguage" literature and the strategies authors adopted to represent that diversity. Even limiting our discussion to the ten stories from prewar Brazil included here, we find that while that alterity is almost always present, it takes different forms from story to story. These various forms of representing the language of the Other throw into question the stability of the language from which that putative deviation is implied. The texts also help us to distinguish between the representation of a linguistic barrier and the reproduction of that barrier, even as they remind us that such a distinction will vary from reader to reader depending on his or her own linguistic competence.

\section{STRATEGIES FOR REPRESENTING LINGUISTIC DIVERSITY}

The first tool to consider when examining representational strategies for linguistic diversity is the furigana. One standard translation of the term into English is "phonetic gloss," stressing the function of these supplementary scripts to provide an indication of the oral component of the primary script. ${ }^{4}$ I use the hierarchy of "primary" and "supplementary" for three reasons: first, because of a "commonsense" understanding of them, which can be useful even if we ultimately question that insinuation of inevitability; second, because of the way in which the furigana is often treated as optional, and will sometimes be added or removed by editors in subsequent editions of texts; and third, because of the fact that it is often presented in ways that make it appear to be of secondary importance. This secondary importance is implied graphically in the form of smaller typefaces (rubi) and interlineal positioning, vis-à-vis the dominant formatting of the texts. ${ }^{5}$ This hierarchy deserves to be questioned, but that will not be the goal of this study. Instead, the focus here will be to identify some of the ways in which these scripts are applied in this particular milieu to represent linguistic diversity. ${ }^{6}$

One primary way for a furigana to be used, consistent with the understanding of it as a phonetic gloss, is to represent (as closely as possible given the limitations of the chosen script) the way the word would be enunciated in the given diegetic context, while the primary script represents the meaning of those words in a more accessible (linguistically conventional) way. The mere presence of furigana suggests 
either that an alternative reading exists, or that some readers would require the clarification it provides. To think of furigana as the spoken version of the written language present in the primary script, however, is insufficient. Ultimately, what a furigana does is juxtapose two scripts in a way that produces more meaning than a single script alone; while convention will guide readers in determining the implications of that juxtaposition, in the end the interrelation of the two scripts is ambiguous and thus open to interpretation. This ambiguity allows for authorial experimentation in utilizing the secondary script.

For example, a furigana may be used to present a transliteration of a non-Japanese word and then provide a Japanese gloss for it. In some cases, the gloss is present not in the subordinate interlineal position, but in the primary position. For example, in "An Age of Speculative Farming," the gendered epithet puta was in its first printing inscribed “賣笑婦”; in this case, the primary script presents in kanji the word conventionally read baishōfu (prostitute), and then gives it a gloss of puuta (sic). ${ }^{7}$ In a way, the primary script is not so dominant at all, in that it functions as a semantic gloss on the oral component, which is in this case the focus. The epithet appears as part of dialogue, as direct discourse, suggesting that the phonetic guide captures the (diegetic) verbal utterance, rather than merely conveying the reading. ${ }^{8}$ Because the first portion of the same dialogue is in Japanese without any alternate gloss, implying that it would have spoken by the character in Japanese in the scene, this gloss likely indicates to us the multilingual nature of the character's verbal abuse.

We may note that the author of this story did not feel the need to provide a similar semantic gloss to a word that appears in the sentence immediately preceding this dialog: ヴァガブンド (vagabundo). This is a choice on the part of the author (or his editor); the semantic gloss provided in the previous example is, after all, optional. Perhaps the author felt that the word had sufficiently entered the vocabularies of his likely readers and thus did not require a gloss, or perhaps he felt that there was no single Japanese word that could capture the precise meaning or nuance of the term. Not surprisingly, different authors could (and did) make different choices. While this author used the term ソルベツチ (sorubecchi) in the same story with no semantic gloss, Sakurada Takeo, writing for a similar audience a little more than eight years later, chose to inscribe the same word as 浆菓”㫗. Sakurada's primary script here presents the word typically read kōrigashi (ice cream) juxtaposed against the phonetic gloss (slightly different from Sonobe's) Y ルヴェッチ (soruvecchi). ${ }^{9}$ Collectively such terms are often referred to as koronia$g o$, Portuguese lexical items that were incorporated into the dialect of Japanese used in Brazil. Unglossed koronia-go, though differing in frequency of use from one author to another, are not uncommon in the stories.

Nishioka Kunio's "The Death of a Certain Settler" contains a similar number of non-glossed koronia-go terms but goes further in the demands it places on its readers' comprehension of the language. To begin with, he never accompanies any 
of these terms with a semantic gloss; though some readers not familiar with Portuguese might have been able to glean the meaning (or approximate meaning) from the context, the information gap would have been noticeable. This is particularly true in the cases when Nishioka made the uncommon decision to use not only Portuguese nouns, but verbs. Consider this passage:

The following day [ ... ] after the camaradas had gone out carpir, Daisuke was stacking, one-by-one, the bricks from the terreiro extension near the main house. ${ }^{10}$

The nouns would be difficult enough for a reader unfamiliar with Portuguese and the specific context of a coffee plantation in Brazil, on the one hand providing a faux ami in camarada that might be taken to mean comrade when it fact it is referring to a farm hand, and on the other presenting a term (terreiro) specific to the cultivation of coffee that refers to a flat, open (and in this case temporary) terrace used for drying coffee beans. It is hard to know what such a reader would make of the phrase containing carpir (to hoe weeds), カルピーに出た (karupii ni deta, gone out to hoe weeds); it seems possible that such a reader could have mistaken its grammatical function altogether, taking it as referring to a place rather than an action. Nishioka uses Portuguese verbs, as he does here, two additional times in the course of the story. ${ }^{11}$

The way in which Portuguese terms were used in the stories differed depending on the author. Unlike Nishioka, the author Takemoto Yoshio indicates to readers that the Portuguese term will function as a verb by following it with the Japanese "o suru" (to do X), as he does with the term colhêr (to pick, pluck, or gather) when he writes, "We must colher the berries, because they will fall from the trees" (珈 琲が落ちるからコロアをしなければならぬ). ${ }^{12}$ Some authors avoid the use of these terms adopted from Portuguese altogether. Perhaps unsurprisingly given the setting of the story (mostly in Japan) and the high level of formality of its language, Katayama Yōko's "Natsuyo" uses none, even when the setting abruptly changes at the end of the story to the contemporary moment in Brazil. There, when the narrator writes, "I now pass my days happily here, in the colony," the term "colony" appears as 植民地 (shokuminchi), rather than the more common コロニア. ${ }^{13}$

Sakurada Takeo's "Placement," which begins with its characters about to enter the Mekong Delta, contains no Portuguese terms until-understandably-the characters arrive in Brazil during the third installment. ${ }^{14}$ Most of the Portuguese terms Sakurada uses in this story are, or could be taken, as proper nouns, and thus arguably do not need a semantic gloss to perform their function; the one exception is ガルガンテ (garganta), which also lacks a semantic gloss. ${ }^{15}$ In fact, the use of this term might be particularly misleading to a reader possessing a familiarity with English but not Portuguese; in the passage, the speaker is comparing an old man to a large tree, which might lead one to guess that the term is a cognate of "gargantuan." Instead, it is a sudden reference to the man in question directly, rather than through the metaphor of a tree. The figurative meaning of garganta (blowhard or 
braggart), which is how it is used here, emerges from its literal meaning (throat or gargle), which in turn comes from the same onomatopoeia (of gargling) that results in the verb gargarejar (to gargle).

This discussion of the boastful man who is likened to a great, old tree is instructive for yet another reason: it occurs in a different form of linguistic diversity, regional dialect. A number of dialectical elements in the brief quote (haiyottoru, desu tai, desu bai) all suggest a speaker from Kyūshū, even if the precise origins of the character might not be identifiable to people unfamiliar with dialectical differences existing in that region of Japan. More important than the precise origins, however, is the fact that the speaker is clearly marked as linguistically Other, as compared to the "standard" Japanese-using characters who are the primary focus of the story. Along with that difference come common (often discriminatory) associations with provincialism, such as a presumed lower level of education. Thus, while most readers might not have hesitated to label this dialogue "Japanese" along with the rest of the story, it is rendered in a way that is meant to distinguish it from "standard" Japanese.

Furuno Kikuo's story "Tumbleweeds" can only be considered in this context tentatively, as the original 1940 version of the story seems no longer to be extant. The earliest version we have today, which appeared in Bungei shuto in June 1958 in Japan, was published with a different readership in mind. It is therefore possible that additional glosses were added for that readership, which could not be expected to have knowledge of the terms. The main text of the 1958 version provides semantic glosses in kanji to katakana in the interlinear position, which itself transliterates the Portuguese terms. There are instances in which this plays a diegetic function, as the semantic gloss supplementing the phonetic component provides information of which the speaker herself is unaware. For example, after one character recites a poem in Portuguese, a young girl (a native speaker of Portuguese who is presumably capable of some Japanese) asks what the word saudade means: “追”憶って、なあに?” The semantic gloss, conventionally read tsuioku (reminiscence), provides for readers the precise information that diegetically the enunciation is meant to elicit.

Unlike previous stories, "Tumbleweeds" sees the glossing of complete phrases with idiomatic Portuguese, such as “俺 知らん“ (Eu não se), especially in dialogue; it also occasionally drops the semantic gloss, perhaps in some cases because a translation of the original Portuguese would be considered too rude (or clumsy), as in “チェッ! プータ・メルダ!” (Che! Puta merda!) ${ }^{16}$ On the other hand, there is little glossing of single terms, especially when they appear in the narrative portions of the story. This is also true in Sugi Takeo's "Revenge" (1938), though it is worth noting that none of Furuno's and Sugi's stories contains more than ten such terms.

One also sees in "Tumbleweeds" references to regional Japanese dialect, whether it is the Kyūshū accent that Akita uses when addressing his mother, or the 
thick Osaka accent heard emanating from the third-class dining hall. ${ }^{17}$ While both of these dialects are explicitly identified within the text, the first is barely represented in the dialogue (agemassho rather than agemashō), while the second is represented at greater length: "Ma, sonai shiyaharan ka te ee dassharo, naa, anta-han, ate kara mo owabi shimassa kai ..." (There's no need for that-I should apologize too. $)^{18}$ It is important to note, though, that standard Japanese, which is used almost exclusively in narrative passages and when depicting the speech of characters who are being elevated (in terms of education, in particular), marks dialect as something that others-and inferior others at that-have, but that the main character and those he (most focal characters are male, with the conspicuous exception of Katayama's narrator) identifies as peers do not have. The use of standard Japanese, then, reflects the character's lack of awareness of his own dialectical specificity even as it is a claim to urbanity and education. Through this language the narrator is tacitly marked as normative while the dialect speakers are marked as deviations.

Another way that linguistic difference "within" Japanese is marked is when a Japanese-American college student, Tani, calls out to his Japanese shipmate upon their approach to Japan that sakura (cherry blossoms) and musume-san (young [Japanese] women) are now visible on the horizon. The use of katakana to represent these two words seem to suggest that the speaker is using them, but somehow incorrectly or unnaturally. The student's utterance as a whole is worth examining, however:

八ロー! ミスタ・秋田！起床々々！水平線にサクラとムスメサンが見えて ますよ。("Hello, Mister Akita! Wake up, wake up! You can see cherry blossoms and young women on the horizon.") ${ }^{19}$

The script choices seem to be implying that the Californian is primarily speaking in English, while also employing the common Japanese terms sakura and musume. Were this not the case, these common terms would not be inscribed in katakana, when the more difficult terms kishō and suiheisen are not. Tani, the story seems to imply, is able to use the first two terms precisely because they are common and easy to remember. Presented in katakana, the implication is that Tani uses the Japanese terms sakura and musume, but that their use is unconventional-primarily because he uses Japanese words amid an English-language statement, but possibly also because his pronunciation is non-standard, further highlighting his alterity. Here, the inscription choices paradoxically connote the opposite of what they normally connote: the use of conventional Japanese orthography for the latter indicates that those terms are expressed naturally (for Tani), and thus are (diegetically speaking) English utterances.

In "Tumbleweeds," there are also cases in which Portuguese (albeit incorrect Portuguese) appears in the text in Roman script, such as the couplet excerpted from the poem "Natal em Paris" by Luís Edmundo in the story "Tumbleweeds": ". . Oh, neve, como a saudade, caes leve, caes leve." In this case, the couplet is 
followed by a parenthetical translation in Japanese ("The snow falls, like a memory, so lightly, so lightly. ...") Later in the story, Roman script appears again when the Latin "Va victis" (sic, "Woe to the vanquished!") appears in the story, followed by a similar parenthetical translation in Japanese. ${ }^{21}$ This, in and of itself, is not surprising; authors in Japan had long experimented with using Roman script (inscribing a variety of languages, including Japanese) for all or part of their texts. What it does remind us, though, is that authors would have been limited by the printing capacities of their publishers as to what scripts they were able to use. There are cases of publishers in Japan being willing to create type for authors, but it is unlikely that any Japanese-language printers in Brazil would have had the capacity to do so. As a result, the writers examined here would have been limited to a conventional set of Japanese type (often purchased from Japan, but in some instances apparently purchased secondhand from Japanese printers in the United States) and a set of Roman type necessary for composing English and Portuguese. ${ }^{22}$

As suggested above, non-conventional orthography (and spelling) is often used to convey non-standard (sometimes non-native) pronunciation. For example, in "An Age of Speculative Farming," when the half-Japanese Hanaoka Ruriko addresses her lover, his name is transcribed in katakana (オームラ), whereas when it appears in narrative passages it appears in the more conventional kanji (大村). ${ }^{23}$ More importantly, when his name appears in dialogue spoken by the native Japanese-speaking Kurose, it also appears using kanji. ${ }^{24}$ The implication is that Kurose's pronunciation of Ōmura's name is normative, whereas Hanaoka's is somehow non-normative, and perhaps even "foreign." We might note that the script choices for the character of Hanaoka may also have the effect of highlighting her otherness; rather than using solely kanji or hiragana, her given name uses a combination of katakana and kanji (ルリ子).

Another scriptural innovation (or transgression, as it is not subsequently acknowledged by the normative center of the language's use) that is present in “Japanese-language" texts in Brazil is a domestically created character (国字), where the "domestic" space in question is not Japan, but Brazil. The primary (and perhaps sole) example of this is the character for mil-réis (金+千), which appears in "Placement" and which was in common use in Brazilian newspapers. ${ }^{25}$ In the context of that story, the meaning would have been reasonably clear even for a reader who is not familiar with the character, despite the absence of either a semantic or phonetic gloss, because the sentence in which it appears states an equivalence of value of 10 of this unit at 2 yen, 50 sen; it further makes it clear that the speaker considers it an unreasonable price for one dozen daikon. The context, therefore, provides a general semantic gloss to this character that would have been very familiar to readers of Japanese in Brazil at the time, but which would have been unfamiliar to readers elsewhere.

These examples drawn from stories written in Brazil remain relatively straightforward, and do not represent a unique formation in Brazil; more complex cases exist in literary texts produced elsewhere. It is worth, then, turning to the related 
(but not symmetrical) phenomena of literary texts written in Japanese by bilingual Korean speakers. Kō Youngran, for example, writes about representations of multilinguality that appear in Chang Hyŏk-chu's (Chō Kakuchū) 1932 story "Gakidō" (餓鬼道). In the dialogue section that she uses as an example, the primary script provides a semantic gloss to the interlinear script, which uses katakana to represent phonetically the discussion that is presumably occurring, diegetically, in Korean. She notes, however, the addition of an unusual element to the dominant script lines, an element that exceeds the lines' function as semantic gloss. Here is an example:

$$
\text { 「馬山イ。ざささと帰れよ。」 (“Maasan, go home right away.”) }
$$

At first glance, this sentence seems to use the primary and interlinear scripts to convey the same sentiment in the two languages: "Masan[-i]. Ŏsŏ toragage" (Korean) and "Maasan. Sassa to kaere yo" (Japanese). At closer inspection, however, one realizes that it is not that simple. For one thing, a Korean speaker would have to understand not only katakana in order to access the phonetic transcription, but also the Japanese sentence in order to provide the necessary clues to decode that (rough) transcription. Additionally, for the sentence to seem natural (as a Korean utterance), the "Korean-language" reader would have to drop down from the supplementary script to the primary script in order to include the $イ$, without which the sentence ("Masan. Osŏ toragage") seems unnatural; of course, such a reader would also have to know not to drop down and include the れよ after the second part of the phrase. Similarly, as Ko points out, for a "Japanese-only" reader, not only is the secondary script merely a collection of sounds that would be incomprehensible beyond the simple fact that it (presumably) represents Korean, but also the $\Upsilon$ would appear as "noise." ${ }^{26}$ It is possible that it would perform that function that Kō suggests for it-conveying the sound of this multilingual environment to readers who do not have the linguistic tools to comprehend that environment more fully-but it would carry little semantic meaning beyond that.

Writing about the particular demands on the Japanese script system in literary texts that arose from Japan's colonization of Korea, Kō explains that most scholars start from the assumption that in Korea during that period the two languages were stable linguistic spheres that did not encroach upon one another. ${ }^{27}$ As she shows, however, not only is the use of script not that simple, but the effect differed dramatically depending on the linguistic capacities of the readerships. As a result, in examining such a text-or, I would add, any text-Kō argues that one cannot rely on an ethnocentric perspective (民族主義的遠近法) that imagines nation-states with discrete and homogeneous national languages used by ethno-national subjects. ${ }^{28}$ Instead, one must see these authors as experimenting with the script tools available to them (linguistically or mechanically) to capture the linguistic diversity they wish to represent, in some cases cognizant that different readerships would have varying degrees of access to those representations. In the case of the stories from Brazil, the depictions of linguistic diversity would not be opaque for some, 
but instead would reproduce a linguistic environment that does not adhere to the putatively clear boundaries between languages; for others, the texts would reproduce its incomprehensibility.

One more point to consider is the fact that the two languages do not exist in a symmetrical relationship; there is always a pragmatic element to the codeswitching, and each language carries an array of social implications. That is, the languages exist in a hierarchical relationship, though the nature of that hierarchy might shift depending on the situation and the speaker. When Luísa or João uses Portuguese in "Tumbleweeds," the implication is of their alterity, and perhaps their linguistic inability to convey the same thoughts in the primary language of their interlocutors. By contrast, when Akita uses Portuguese, that act of codeswitching demonstrates his intelligence and greater range of linguistic (and, by extension, cultural) awareness. The code-switching is not only a linguistic device, but a literary device meant to reveal aspects of the characters and their relationships to one another indirectly.

Yet another point to consider is the issue of comprehension. As Naoki Sakai argues, failure of communication is not limited to interactions that occur across a presumed language barrier (with one or more of the participants operating, by definition, outside of their first language). Sometimes, however, literary texts downplay such barriers, not fully acknowledging the challenges of comprehension even when they exist in more conventional forms "across languages." ${ }^{2}$ If the narratorial perspective implies that the reader's knowledge of events is dependent on a given character, the presumption is that such knowledge would be dependent on that character's capacity to understand the "alien" (vis-à-vis the language of the narrative itself) language. Such cases are rare in the stories examined here, for reasons examined in the previous chapter. Perhaps the most substantial example involving direct discourse attributed to a character marked as non-Japanese is the following phrase, uttered by the Baiano worker in Nishioka's "Death of a Certain Settler":

Patrão, she didn't eat anything today either, a-and she's in her last month of pregnancy so she can't work, she's in a tough spot. I-i-is there any way you could let her have um plato of food? I will gratefully put in an extra hard day of work tomorrow in return. ${ }^{30}$

Given the improbability that the Baiano laborer had acquired sufficient Japanese ability, the implication is that this dialogue would have occurred diegetically in Portuguese, with the titular settler, Kaneko, then "interpreting" it in the story for a Japanese-reading audience in Brazil; presumably that audience would be comfortable with the untranslated terms patrão and um plato.

In the end, however, this is not a real multilingual situation, but a fictional one. The author is aware of what each character says, even if the narrator perhaps might not be, as each character is the author's creation. It is awareness of this 
fact, presumably, that invites the reader to trust the narrator's (or focal character's) understanding of those utterances. This is akin to the difference between a dramatic scene, in which the conceit is that the reader is watching the event unfold along with the characters involved, and a retrospectively reported event, in which the reader is asked to believe the account presented by a (non-omniscient) narrator. While the latter might more clearly raise the possibility of an unreliable narrator, the former-in this case, the non-diegetically interpreted utterance-might be worthy of similar scrutiny. In such scenes, when presented from a narratorial perspective that is not omniscient, we do not hear what the other (non-focal) characters say; we are told by a narrator what they said.

Language diversity might also be presented in a text with comprehension being beside the author's intended point. Nishi Masahiko writes about how other languages can be used in monolingual novels not to reveal the fissures that they would inevitably reveal in life, but rather to titillate, as mere exoticism or "local color." While Nishi does not mean that these linguistic elements are trivial, the use of such terms and the negative (and dismissive) connotations that cling to them runs the risk of devaluing a linguistic diversity that performs multiple potential functions within the texts. He likens the monolingual rendering of the multilingual environment to an invisibility cloak (隠れ袁) that conceals fierce ironies that function in the texts that emerge from such an environment (in his case, colonial Taiwan). ${ }^{31}$ He provides the useful thought experiment of imagining how one would handle the linguistic elements of a film adaptation of such a work. Ultimately, however, we as readers are not limited to the intentions of the author, and therefore are free to draw meaning from a text's treatment of linguistic complexity and the potential barriers to communication that might result from it. This is not only true in texts that contain scenes of multilinguality, commonly defined; it is also true of texts that "only" contain "Japanese," especially given the complex and diverse history of language practices that are grouped under that broad rubric.

\section{NIHONGO BUNGAKU: JAPANESE-LANGUAGE LITERATURE}

Despite this linguistic complexity, and the examples of unconventional representational tactics that authors have used to capture it in literary texts, such fiction (in Brazil or in Japan) remains largely monolingual or provides sufficient context to enable a monolingual reader to comprehend it sufficiently. As a result these texts, as diverse as the language environments they depict-or encode-may be, are often seen as being written in Japanese. It is this point of commonality that critics have focused upon in recent years when thinking of literary texts collectively, rather than through any of the logics raised in the earlier chapters, in a move toward inclusivity for authors who do not conform to a normative ethnic 
identity. Nihongo bungaku (日本語文学), or Japanese-language literature, is fast becoming the rubric employed to distinguish such texts from Nihon bungaku (日 本文学). ${ }^{32}$ The new category began being consciously deployed for this purpose from the 1990s, but it appeared occasionally before that as well, though then its evocation seems to have been less strategic and its meaning treated as more-or-less self-evident. ${ }^{33}$

One of the earliest proponents of the term was the writer Kim Sŏkpŏm. ${ }^{34}$ Hirata Yumi describes the ways in which Kim used the term from at least as early as 1972 to explicitly comment on the ways in which Zainichi Korean literature had been marginalized from a normative notion of Japanese literature. ${ }^{35}$ She also describes how other authors were concerned with similar issues even if they did not use this precise terminology; the example she gives is Ōe Kenzaburō in a published discussion with Gotō Meisei and others from 1970. ${ }^{36}$ For his part, Kim felt that when Zainichi Korean writers, whose language and country had been stolen from them and who were forced to live "another's history," had no choice but to write in the language of those who had stolen those things from them, what they wrote could not be called "Japanese literature." That concept, based on the presumed unity of state-language-ethnos, which had been used to build the modern nation-state of Japan, failed to reflect the more complicated reality of writers who had come to the country by force, for economic or educational opportunity, or as refugees, but did not identify as Japanese; the concept of Japanese-language literature, in Kim's mind, more effectively problematized this history. ${ }^{37}$

Around the same time, two articles were published that associated the concept of Nihongo bungaku with the Japanese-language literature produced in Brazil. Despite not employing the phrase as an alternative to Nihon bungaku, the authors clearly revealed many of the same concerns that drive the proponents of Nihongo bungaku today.

The first, "Dying Words: The Japanese-language Literature of Emigrants to Brazil” (失われる言葉・ブラジル移民の日本語文学), appeared in the Yomiuri shinbun on 25 April 1969. The author, Yabusaki Masatoshi, himself an emigrant to Brazil, was born in Tokyo in 1922 and made the passage to Brazil with his family in 1933. Yabusaki was central to Japanese-language literary activities in the postwar, some thirty years after the end of the period being examined here. According to the brief biographical note that accompanies the article, in 1969 he was working at a Japanese bookstore in São Paulo and editing the literary magazine Koronia bungaku.

In the article, Yabusaki describes how extensive the Japanese-language literary production of the community is, given its small size: multiple daily newspapers and monthly periodicals that carry fiction, and roughly as many literary awards as there are publishing venues. With thirty to forty submissions for each award every year, he estimates that as many as one hundred works are being composed for consideration annually. Yabusaki continues, saying that the population of Japanese 
speakers (日本語使用人口) is estimated as being just short of 100,000, and suggesting that a notably large fraction is engaged in creative writing. ${ }^{38}$ He then offers an interesting observation: while it is obvious from these figures that Japanese migrants are passionate about fiction, it is not at all clear what they are trying to achieve with it. Rather than being engaged in a literary endeavor that produces lasting masterpieces, he imagines that they engage in the writing of fiction in a more casual and ephemeral way, as when one tells stories of the past while sitting by a fire.

For Yabusaki, the Japanese language and its use for literature are in crisis in Brazil, partly due to a lack of influence from the language as it is used in Japan. He opines that the Japanese language used by writers there is the one they brought with them when they migrated as many as forty years earlier, and as such has long been removed from the feel of vivid daily life (鮮やかな生活感覚); the result is that the functionality of the language has deteriorated. Without interlocutors, Japanese migrants can only use the language to speak amongst themselves; the absence of true dialogue can only lead to a “deformed" (不具) version of the language. Despite the daily deterioration of the migrants' Japanese, no other language takes its place; only those who were born in Brazil or came as children can really enter the Portuguese-speaking world. The presence of two idiomas (glossed as 国 語, and thus indicating dominant languages for their respective speakers) creates a divide between the generations, so that when migrants try to tell their stories to their children, hoping that the tales will live on in the children's memories, they discover that they cannot. When they realize this, they turn toward their homeland (故国) and think to tell their stories to the people there, but here too they fail; the result is confusion about who they themselves are, and a sense that their words/language (言葉) have become frustratingly impoverished. Only if the migrants invest the necessary labor in self-examination and restoring their dying language, Yabusaki offers, do they have any hope of someday joining a "world of dialogue" (対話の世界). In different terms, Yabusaki is claiming a form of dependence by the periphery on the center; I will return to this notion in the conclusion. To return to our present discussion, the term Nihongo bungaku does not appear in this article beyond its title; there it is presumably being used in a less consciously strategic sense, to denote what the article goes on to describe as "works told in Japanese” (日本語でつづられる創作) and to connote works produced outside of Japan, where the language of composition could (in theory) remain implicit.

By the time the term was used again in the newspaper, six years later, it was being used in a more intentional manner. On 2 April 1975, the Yomiuri shinbun ran an article titled, "Japanese-Language Literature Abroad: The Stories Told in Nanka bungei and Koronia bungaku." The author of this article was Ōta Saburō, a professor of Comparative Literature at Chiba University. In it he took up two literary journals published in the Americas: Nanka bungei, published in Los Angeles, which had just produced its twentieth issue; and Koronia bungaku, published in 
São Paulo, which had already released twenty-five issues. Both journals had been established a decade earlier. Öta refers to these as the two representative journals of Nihongo bungaku of the day. The article then goes on to define the phrase indirectly, as referring to the literary activities of Japanese who had migrated abroad, and naming the writings emerging from the West Coast of the United States as its earliest examples. Shortly after their arrival in Seattle, San Francisco, Los Angeles and other cities, the Japanese migrants had attained a sufficient level of economic stability, Ōta explains, to make literary activities possible in much the same way those in Brazil did a little later.

Focusing on the re-emergence of these literary activities in North America after the chaos caused by the internment, Öta states that the dramatic gains seen recently (since the 1960s) among individuals of Japanese descent are actually limited to those who have assimilated into American society; those who instead "do not lose their Japanese consciousness and emotions, and preserve their Japanese language" are not fully assimilated. Ōta too points out that second- and third-generation Nikkei are raised speaking English, and that for them Japanese is nothing more than another foreign language. In the prewar, Nihongo bungaku comprised the works produced by these first-generation migrants who "lived seeing themselves as Japanese” (日本人意識に生きる). The result, according to Ōta, was works in the realist mode that dealt solely with the issues that plagued the Japanese immigrant community. ${ }^{39}$ Öta contrasts this with the situation as he understands it in Brazil, which saw greater continuity between the literary activities of the prewar and those of the present day (1975) thanks to less challenging circumstances for the community in the country during World War II. Ōta describes the impetus behind the creation of the literary magazine Koronia bungaku as being the desire to write down their experiences, as a part of a single human history (一つの人間の歴史 とて), and to do so in Japanese, even as second- and third-generation Nikkei are losing their connection to the language.

Öta argues that the very act of composing works in Japanese at its heart reveals that these individuals are powerfully conscious of themselves as Japanese. The works emerge from the experiences that Japanese only have once they are present in a foreign society, and give them the opportunity to reflect on the essence of Japaneseness. But, Ōta cautions, because these works cannot be read by second- and third-generation Nikkei, they will disappear along with the first generation, just as those migrants fear. Having said that, Ōta also offers the possibility that Nihongo bungaku could pioneer new territory if it follows the example set by Ōba Minako, whose works are not fixed in a given ethnicity, but instead deal in universalities. The conditions for such a development, Ōta notes, are more present in foreign countries than they are in Japan.

Ota does see one way for these texts to live on and for them to be of value to Japanese in Japan at the same time. He urges readers in Japan to read these works, which reveal the true nature of the Japanese by depicting their experiences abroad. 
The works are valuable because they allow those readers (here presumed to be Japanese) to remind themselves of what it is to be Japanese. If these texts are not read in Japan, then foreigners (外国人) will pay no attention to them. Eventually their authors will die and all trace of the works will disappear. They must be taken up "as a special area within Japanese literary history"; to do so would be to support those individuals who have developed Nihongo bungaku.

These two articles anticipate scholarship that begins to emerge quickly from around 1990, though there are at least two key differences: the first is that the later works are deploying the term Nihongo bungaku more consciously, more strategically, than do these articles, which seem to treat it more as a self-evident descriptor, even as they are clearly using it to identify a non-normative form of Japanese literature; the second is that the later scholarship tends to use the term primarily to discuss works written by writers who do not identify as ethnically Japanese, and whose relationship with the Japanese language is related to the Japanese imperial period. It is not surprising, then, that two of the earliest monographs employing this term as a central concept were themselves focused on the Japaneselanguage literary production of writers who identified ethnically with Korea and Taiwan, respectively.

The former was Hayashi Kōji’s Zainichi Chōsenjin Nihongo bungakuron (1991), which was based on articles that the author published over the previous decade addressing ethnically Korean Zainichi writers. Given the perspicacity with which he deals with many of the relevant factors, it is worthwhile to overview some of the logical steps that he takes in laying out his argument. Hayashi begins by establishing a distinction between the language of an author's motherland (母国語) and an author's mother tongue (母語). In Hayashi's view, for resident Koreans in Japan (在日朝鮮人) the former is always Korean, though they may not be able to speak it at all; the latter is one's first language (that which one "naturally acquired from birth as one's mode of expression"), and therefore may be Japanese, especially in the case of the second and third generations. ${ }^{40}$ For individuals such as these, Korean can become a “non-mother tongue" (非母語), which Hayashi suggests may simply mean a second language. It is interesting to note that when Hayashi uses Kim Tesen as an example, he is forced to acknowledge a further complexity to the languages involved: since Kim was born and raised (until the age of five) on Jeju Island, the Korean he uses, his mother tongue, differs from the "standard Korean of modern Korean literature" as result of Jeju Island's relation to the rest of Korea, which is similar to that of "Okinawa's position within the Japanese language sphere." According to Hayashi, for Kim, Japanese is a "pseudo-mother tongue” (疑似母語), acquired naturally from the age of five when he moved to Japan to live with his "aunt," who herself was a "pseudo-mother." It is also a "halfmother tongue” (半ば母語) that functioned as his language of daily life (生活言 語). Hayashi is right to identify the political context within which there arose these subjects, the Zainichi, for whom the language of the motherland and the mother 
tongue were not identical. He describes various historical paths that led to this disassociation for different authors over the course of the twentieth century and is careful to note the role played by Japanese imperialism. For Hayashi, languages are products of ethnic histories; as a result, the relationship between the Korean and Japanese languages cannot be discussed without taking into account the history of Japanese invasions of the Korean peninsula. At the same time, Hayashi acknowledges that as the distance of these subjects from the Korean language increases, their relation to the language becomes ambiguous, and that their ethnic consciousness as Korean (朝鮮) approaches nil, particularly when their parents' mother tongue was Japanese. The force, in fact, that might cause them to come to possess this consciousness is social discrimination. ${ }^{41}$

As for how these issues related to the questions at hand, about aggregated textual rubrics, we see in Hayashi awareness of what I consider to be the key issue: if one explores the question of what the Japanese language is to Zainichi subjects, one must also ask what it is to Japanese subjects; if one asks what Nihongo bungaku is, one must also ask what Nihon bungaku is. These are not ontological questions so much as historical and political ones. Hayashi notes the centrality of the modern nation-state's project to normalize (make normative) a standardized national language to the development of modern literature as a whole. It is this process of making literature national, according to Hayashi, that resulted in modern Japanese literature becoming an "ethnic literature." ${ }^{4}$

It is in his use of ethnicity that Hayashi's argument becomes somewhat problematic. On the one hand, he treats the ethnicity of his authors as self-evident, as when he describes Kim Sŏkpŏm as “undoubtedly Korean” (疑いもなく朝鮮人 である), or perhaps as one who has never doubted his identity as a Korean; this is presumably the justification for all of the authors Hayashi studies having some relation with Korean as their bokokugo, which can then also be identified as their language of ethnic origin. ${ }^{43}$ As the country (countries, depending on the historical moment) in question is presumed to be ethnically homogenous, one's mother country becomes the home of one's ethnic origins. In fact, perhaps it might be more historically (though not biologically) accurate to refer to this as their language of racial origin, as their common descent seems to be implied as being an essential component of this ethnic identity.

Hayashi is clear to state that ethnicities are the products of history, and that one implication of this fact is that Zainichi (在日朝鮮人) will gradually grow distinct from Koreans (朝鮮人). ${ }^{44}$ It seems, though, that both of these identities are rooted in something essential, some sort of "Koreanness," that remains unproblematized even as Hayashi acknowledges that it seems bound to result in two distinct identities. One can imagine a number of reasons that Hayashi might choose to leave the historical origins of this (or any such) identity unquestioned, particularly as his ultimate project seems to be to acknowledge and legitimate the writers' own (diverse) relationships with that identity. 
For Hayashi, ethnic identity (民族的独自性) is something that can diminish, and perhaps even be lost, as was the case (he contends) for the writers who participated in the Korea Proletarian Artist Federation (KAPF; 朝鮮プロレタリア 芸術同盟), such as Kim Yonje. Ethnic identity is fluid and not a universal (or ideal, or essential) entity, he argues. One of the results of this is that for some second-generation writers, the identity (属性) that they desire is not “Korean," but Zainichi, an identity that does not oppress them, but rather feels natural. Hayashi also recognizes the material ramifications of an author's language choice, as when he discussed the author Chang Hyŏk-chu. Hayashi describes the way in which Japanese functions as a world language for Chang, allowing his works to reach a broader, global readership as part of the "commercial literary establishment" (商 業文壇). The desideratum of writers like Chang was exposure to a larger public (公共性). ${ }^{45}$ In both cases, he acknowledges the role of history, and the capacity for change.

Despite Hayashi's calls for historicization, there nonetheless remains an element of essentialization, as can be seen when he writes, "Despite the fact that today's 'Zainichi Korean Literature' is written (expressed) in Japanese by people living in Japan, there is an aspect of it that cannot be referred to as 'Japanese literature." He continues, "Yi Yang-ji first produced Zainichi Korean (朝鮮人) Literature when she sought for some sort of positive capacity in the fact of her Koreanness (朝鮮 人である事実).”46

Fundamentally, however, Hayashi is committed to the capacity for historical change, even if he only explicitly acknowledges it prospectively. He also notes the presence of conservative forces that will deny the transformations that accompany the passage of time, which will withhold recognition of these new forms as literature through the exercise of authority. He also makes the following assertion:

Whether or not it is necessary for a Zainichi Korean to identify with “Korea” (朝鮮) is a question that requires us to consider a variety of social conditions, but speaking about literature as viewed from the 'bird's eye view' of ideals, it is not necessary for Zainichi Koreans to be Korean. The value of Zainichi Korean Literature is unrelated to whether or not the author is Korean.

He makes it clear, however, that to think of literature outside of its historical context, as a universal phenomenon, is a dangerous sign. ${ }^{47}$

Hayashi supports Kim Tesen's argument that literature must free itself from notions of identity (帰属観念), including those toward ethnic languages (民族語), and eliminate any constraints on the choice of language used for literary expression. Once this is achieved, he argues, "modern" literatures, which were from the beginning presumed to be ethnic literatures written in ethnic languages, will be rendered obsolete; in fact, "the overcoming of modernity will begin with the collapse (破綻) of ethnic literatures.” Writers, he argues, must not depend upon identification of any sort, be it with ethnicities, states, or any other large organizations 
outside themselves; yet the end result of this for Hayashi is a Japanese literature in which “we” (われわれ) “allow” (許容) Japanese-language literature by a variety of ethnic subjects. Who is the "we" that might allow this? From the context, it would appear to be "internationalized" Japanese subjects, but this Japaneseness seems to still be premised on an ethnic identity. Hayashi sees a dwindling of commonalities (共通項) among the works of Zainichi Korean Literature, with those of the Ikkaino (猪飼野) writers in particular being more writers of minority exoticism within Japanese Literature than of Zainichi Korean Literature. Hayashi believes that it will only be when these writers transcend Ikkaino that they will transcend Japanese Literature. Having said all this, Hayashi cautions that the bonds of "modern ethnicities" (近代民族, glossed as “nation”) are not so easily severed, and that transcendence in the case of Japanese Literature will only occur when [subject unclear, but presumably] Japanese writers produce Japanese-language fiction in proper recognition of the violence (侵略性) inherent in writing in Japanese. ${ }^{48}$

Many of the observations that I wish to make are already present here in Hayashi, particularly when his conclusions are taken to their logical end. Unfortunately, however, he never fully subjects "Japaneseness" and "Japanese literature" to the same historicizing analysis to which he subjects his object of study. By contrast, this move of auto-critique is more present in the second work under consideration here, Tarumi Chie's Taiwan no Nihongo bungaku: Nihon tōji jidai no sakka tachi (1995). ${ }^{49}$ By page seven, she has already identified the capacity of the works she is studying to "undermine the concept of 'Japanese literature' in its narrow sense." Tarumi identifies that the central goal of Japan's imperial policies was to bring the local population under the empire's full control, a process which began with assimilation and then amplified to “imperialization” (皇民化). According to Tarumi, it is this latter process that placed the burden upon the colonized subject to conform to an imperial ideal, resulting in the theme that unifies the works by kōmin writers from Taiwan: How can one become Japanese? It is this theme that leads Tarumi to ask the question, what is it that makes a person Japanese? Using herself as an example, Tarumi admits that she would be at a loss if she were asked to prove that she was Japanese, even as she claims that her Japaneseness is, to her, a self-evident fact. ${ }^{50}$

Tarumi is not merely dealing with questions of ontology; she is clearly aware of pragmatic matters of daily life, including individuals' political identities, linguistic identities, and cultural identities. She notes that while Taiwanese during the period of Japanese control were legally defined as "Japanese," the Japanese language was not their mother tongue (母語) and “Japanese culture" was not what "governed their daily lives.” Yet, she notes that it is a “patent absurdity” (極まりない不条理) that it was Japanese who would declare that Taiwanese were not Japanese. ${ }^{51}$

Tarumi returned to the subject in 2013, and elaborated on the problem facing such writers: 
From the start, the Japanese-language literature of Taiwan, born from the Japanese language education that supported imperial control, is a sort of changeling born of the politics of language. What differentiates it decisively from postcolonial literatures born from the former British colonies is the fact that Japanese itself is a language that possesses almost no marketplace beyond Japan. This means that evaluations of such works are left to Japanese people who understand the language, and the bulk of the works' messages are attended to according to the filter of the Japanese value system.

Tarumi looks forward to a day when Japan will nurture multilingual readers who can understand and appreciate the works of such writers free of such filters. ${ }^{52}$

The later essay appeared in one of a number of recent volumes dealing with Nihongo bungaku, a number of which use it in conjunction with the term gaichi. ${ }^{53}$ This last term was popularized by Kurokawa Sōs publication of a three-volume collection of translations, <Gaichi> no Nihongo bungaku-sen (Tokyo: Shinjuku Shobō, 1996), which featured works written in the former Japanese colonies and quasi-colonial spaces of Asia. By the time Kamiya Tadataka and Kimura Kazuaki took up the term, they had decided to interpret it broadly, to include writers without Japanese citizenship who resided in Japan and those of Japanese descent in Brazil who wrote in Japanese. ${ }^{54}$ In her 2013 edited volume, Kaku Nan'en shifts the focus to bilinguality and to the heterogeneity inherent in the Japanese language itself. In Ikeuchi Teruo, Kimura Kazuaki, Takemura Yoshiaki, and Tsuchiya Shinobu's 2014 collection, the editors responded to some criticisms of the use of the term, particularly from Komori Yōichi. ${ }^{55}$ Rather than problematizing the relationship between Nihongo bungaku and Nihon bungaku, however, Kimura focuses on the referents of the term gaichi. In all three edited volumes, despite the different issues raised by the many contributing scholars, the contents all tend toward authors who somehow deviate from a normative notion of Japanese literature.

In his introduction to the 2014 volume, Kimura draws particular attention to the innovative work of Nishi Masahiko, who has offered the following definition of Nihongo bungaku: "The literature that emerges when Japanese-language speakers (literally, “users” [使用者]) live in constant contact with, or in the proximity of, non-Japanese-language speakers." ${ }^{56} \mathrm{He}$ has made this definition central to his work, though in recent years he has begun to apply it to the terms gaichi bungaku and gaichi no Nihongo bungaku more frequently. ${ }^{57}$ In his case, he utilizes the problematic distinction between a naichi (inner territories) literature and a gaichi (outer territories), employing terms historically used to distinguish the "main islands" of Japan from its colonies. ${ }^{58}$ For Nishi, such literature is marked by three primary elements: the suggestion of other languages, the marks of imperialism, and the presence of "overseas Japanese." ${ }^{59}$ His particularly narrow definition of naichi, in which he hesitates to include Okinawa, combined with his sometimes inconsistent use of terms, appears to reinforce a notion that an unproblematic 
Nihon bungaku exists, when it does not meet the criteria he lays out in the definition of Nihongo bungaku above.

This seems not to be Nishi's goal, as his definition leads him to characterize certain canonical works, such as Mori Ōgai's Maihime (189o) and Yokomitsu Riichi's Shanhai (1928-31) as Japanese-language literature of the outer territories. ${ }^{60}$ Nonetheless, Nishi makes such troubling statements as: "in the same way that the literature of the United States, Australia, and India may be Anglophonic literature but not English literature, so too we can say that koronia bungaku is not Japanese literature (日本文学)" and “[literature by emigrants from Japan] reveals a strong ambition to blow a new wind into the literary establishment of the naichi, using the power of exoticism as a weapon." ${ }^{\prime 1}$ As a result, despite Nishi's move toward inclusivity, toward bringing attention to literary texts that reach in one way or another beyond the main islands of Japan, the logic of his work may have the effect of reinforcing the normative, self-evident notion of a "Japanese literature" that can be differentiated from a "Japanese-language literature."

Similar issues arise in works that have adopted the logic of "border crossing" (越境), with national borders being the primary ones imagined (thus, "transnational literature"), but by no means excluding other possible borders. As the editor of one such volume explains it in his introduction, this approach is an attempt to undertake social critique from a global perspective.

That is, in order to overcome a perspective based on a national language, [this approach] focuses on the postmodern postures of authors who emphasize the body and capture the foreign, and thus is able to involve an investigation into the relation between these authors' work and the current situations into which migrants have been placed. The consideration of these issues from a position that transcends those of the mainstream of world literature or ethnonational literatures is intimately connected to the postcolonial creole-related work (e.g., that of Patrick Chamoiseau and Maryse Condé, among others) and multilingual culture research that is particularly notable in Francophone studies.

Much like the works described above however, this volume too fails to deal clearly with the relationship between these non-normative literary texts and a national literature that is presumed to make up the normative form. Even as Tsuchiya claims that these "peripheral 'minor literatures' enrich the legacy of the various ethnonational literatures," with which they bear a relation, he also sees the non-normative authors and works as being Other to normative ones: "just as has been done with the excellent authors and works that have made up the ethnonational literatures, so too must attention be paid to the excellent authors and works of border-crossing literatues." ${ }^{2}$

The problem with using Nihongo bungaku-or any of these rubrics for that matteralongside the ethnonational rubric of Nihon bungaku is that the former then establishes non-normative subjects who participate contingently (and peripherally) in 
the latter cultural totality, which it reserves for normative subjects who supposedly participate in it organically. ${ }^{63}$ In so doing, it elides the contingent (or constructed) ways in which any writing subject participates in the imagined totality and solidly historical (rather than epistemologically inevitable) construct of Nihon bungaku. ${ }^{64}$ It is not sufficient, however, to merely use the non-normative literary texts to challenge or deconstruct the notion of Nihon bungaku if the result is a new ahistorical conception with slightly modified contents. Instead, an examination of the history of that concept's construction, ideological function, and material ramifications is essential, with a mind to the positionality of its writers, readers, and critics. ${ }^{65}$ As will be discussed in the conclusion, the current study is no exception. 